\title{
The Economic and Non-Economic Determinants of Economic Growth in Oil-Exporting Arab Countries
}

\author{
Elham Mohammad Alhaj Yousef*, Taleb Awad Warrad \\ Business Economics Department, Faculty of Business, University of Jordan, Amman, Jordan \\ Email address: \\ Ehajsuper1@hotmail.com(E.M. A. Yousef), t.awad@ju.edu.jo (T. A. Warrad) \\ ${ }^{*}$ Corresponding author
}

\section{To cite this article:}

Elham Mohammad Alhaj Yousef, Taleb Awad Warrad. The Economic and Non-Economic Determinants of Economic Growth in OilExporting Arab Countries. International Journal of Business and Economics Research. Vol. 8, No. 3, 2019, pp. 142-152. doi: $10.11648 /$ j.ijber.20190803.18

Received: May 8, 2019; Accepted: June 10, 2019; Published: June 26, 2019

\begin{abstract}
This paper aims at exploring the main determinants of economic growth in Oil-Exporting Arab countries (OEAC) by shedding light on the most effective determinants. It is then wished that governments and policy makers would concentrate on and take them into consideration when they are designing and applying their public policies. The study used panel data for six OEAC over the period of 1998-2017. Some study variables were not stationary at level but they became stationary after taking the first difference for them. The result of applying panel Pedroni cointegration test revealed that the model was cointegrated. Therefore, FMOLS model was applied for estimation showing that gross fixed capital formation, labor force growth rate, economic freedom, rule of law, regulatory quality and government effectiveness have statistically significant positive impact on the economic growth of OEAC, while trade openness, control of corruption, political stability and voice and accountability have insignificant effects on their economic growth during the study period. Moreover, the Global Financial Crisis of 2008 with its slow recovery has a significant negative impact on the economic growth of such countries. Therefore, the study recommends OEACs' governments to make "real" institutional reforms and adopt the appropriate polices that eliminate corruption and rent seeking behaviour and enhance the rule of law. They also need to improve the quality of education and to develop the skills and expertise of their labour force. In addition, they have to establish specialization in the production of goods in which they have comparative advantages and diversify their production and sources of national income, and not to depend only on exporting natural raw materials, which altogether eventually ensure resources are efficiently and effectively utilized in pursuit of their economic growth and social development.
\end{abstract}

Keywords: Economic Growth, Arab Countries, Governance, Trade Openness

\section{Introduction}

The economic growth is the main focus of all world countries because it is the basis for achieving economic development, therefore, all governments adopt policies to boost their national income growth rate, reduce unemployment rate, fight poverty, raise education standards, increase investments, support structural changes, innovation, research \& development.

The importance of economic growth necessitates identifying the main determinants of it. There are mainly two types of them: 1- Economic factors: the factors that have direct effects on production process and economic progress such as capital formation, labor force, natural resources, technology, conditions in foreign trade and economic system. 2- Non-Economic factors: the factors that indirectly affect the economic activities through influencing societies' behaviour such as political stability, corruption, the role of government, culture, desire to develop, religion, traditions etc. The economic factors are often more common and used, but the Non-Economic factors have also been commonly used in economic development studies related to the third world countries during the last fifty years. Kindleberger presented many non-economic factors such as family, class, culture, race, religion [23]. It should be noted that these economic and non-economic factors strictly interact with each other.

This study analyzes the impact of the main economic and 
non-economic factors on the economic growth of OEAC using panel data for six OEAC over the period from 1998 to 2017. This paper also explores the most effective determinants of economic growth in these countries, which ultimately help to draw some recommendations that may shed light on them. It is then wished that governments and policy makers would concentrate on and take them into account when they are designing and applying their public policies.

\section{The Problem of the Study}

Developing Arab countries suffer from low growth rates of real gross domestic product (GDP) or even retreating ones, and they are facing tremendous pressure to get the economy functioning in a healthy manner. This important issue became the motive for many researchers to conduct vast number of studies both at individual and institutional levels in order to investigate the main determinants of economic growth and their effects on economic development. Therefore the problem of this study can be considered as one of these studies in which it tries to answer the question of what are the main economic and non-economic factors that could deeply affect the economic growth of selected OEAC and hinder their development.

\section{Objective of the Study}

The main objective of this study is to examine the impact of gross fixed capital formation, labor force growth rate, economic freedom, trade openness, governance and the Global Financial Crisis (GFC) of 2008 on the economic growth of selected OEAC.

\section{The Importance of the Study}

1. This study will help in predicting the growth rate of output and in determining the factors that have the greatest effect on economic growth of OEAC. The most recent years are also included in the study period.

2. It sheds light on the importance of non-economic factors (beside economic factors) as overwhelming factors and responsible for major contribution to economic growth in OEAC.

\section{Limitations of the Study}

This study is limited to investigate the main non-economic factors of economic growth because some of these factors have subjective indicators (culture, race, religion, traditions etc.) and may distort the results or their reading. Some OEAC were excluded from the sample because of the unavailability of all required data during the most recent years. Therefore, the impact of the main economic and non-economic factors on economic growth for six OEAC over the period 19982017 will only be tested.

\section{Hypothesis of the Study}

The study aims to test the following null hypothesis: There is no significant relationship between real GDP growth rate of OEAC and each of: their gross fixed capital formation, labor force growth rate, trade openness, economic freedom, voice and accountability, political stability, government effectiveness, regulatory quality, rule of law, control of corruption and GFC of 2008 with its slow recovery.

\section{Literature Review}

Adam Smith (the father of classical economic) had analyzed economic growth in his famous book The Wealth of Nations, in which he stressed that savings, specialization and division of work are the most important elements in the economic growth process; savings lead to capital accumulation, while specialization and division of work boost the productivity levels which in turn increase wages, incomes and profits. He concluded that some of these profits are saved in order to raise investment until economic growth can eventually be achieved. Recently, the theoretical base of economic growth presented by the neoclassical model of Solow depends on many assumptions such as constant return to scale production function, diminishing marginal productivity of capital, producing one homogenous good, closed economy, absence of government, perfect competition, and the exogenous variables are: saving rate, population growth rate, and technological progress rate [44]. Solow also believed that saving rate (followed by capital accumulation) is the main determinant of economic growth in the short-run, but technological progress is the most important factor in the long-run. Thus Solow model implies that regardless of the economy's starting point the economy will converge to a balanced growth path where each variable in his model is growing at a constant rate.

Many recent studies such as Romer and Lucas have considered technological progress (knowledge, innovation etc.) as an endogenous variable and the major determinant of long-run economic growth $[43,31]$. They determined three main sources of growth: new knowledge, innovation and public infrastructure. They also initiated the famous endogenous growth theory which beats the law of diminishing returns and states that investing in labor, capital, education skills and research and development will increase the labor productivity and eventually boost the economic growth. The augmented Solow model equilibrium presented by Romer is not a steady state, as the economy can continue to grow infinitively [42]. In contrast, Barro found that policies could enhance and boost the economic performance in the long-run [2, 3]. From the perspective of non-economic growth factors, other researchers have emphasized the significant role of institutions in economic growth such as $[32,21,41]$. Some researchers have investigated the effects of social-cultural factors (culture, language, religion, attitudes, race...etc.) on economic growth $[16,24]$. Others highlighted some non-economic factors such as political 
factors, geography and demography [25, 28]. They found that political instability would increase uncertainty which ultimately reduce investment and growth. Other researchers have examined the effects of some demographic factors (such as population growth, population density, migration and age distribution) on economic growth as can be seen in Barro [3]. The results of many studies that investigated the relations between some demographic factors and economic growth were not conclusive and many demographic aspects remain until today unexplored.

Neoclassical and endogenous growth models emphasized the significant role of investment in economic growth which led to the emergence of huge amount of studies that analyzed and tested the relationship between economic growth and investment [25, 39]. In addition, Lensink and Morrissey concluded that the role of foreign direct investment in growth and technology transfer can't be ignored [29]. On the same line, Kandenge used the framework of an endogenous growth model to investigate the impact of public and private investment on economic growth in Namibia [22]. He found that public and private investments, exports, imports, economic freedom, labour and human capital have significant positive impact on short and long-term economic growth. On the other hand, human capital (educated and skilled workers) has been investigated by Barro and Brunetti who found a significant positive relationship between educated population and economic growth $[2,8]$. In addition, endogenous growth models have emphasized the vital role of innovation, research \& development and technology in increasing productivity levels and economic performance, and many studies have proved the positive relationship between them $[30,46]$. The significant relationship between economic policies, macroeconomic conditions and economic growth was confirmed in some studies that stressed that institutions, stable macroeconomic conditions and a little of uncertainty have an important impact on economic growth [25, 2, 3]. In fact, all economic theories have affirmed the positive role of capital accumulation or investment in the economic growth and development, and they agree that improving the business climate is very important in attracting both national and foreign investments, which ultimately will boost economic growth. Investors will stay away from a politically instable, bureaucratic and highly corrupted country, in which its government is not delivering its services efficiently and transparently [17, 36, 13]. Instead of that, accountable, efficient and effective government in delivering public services and who responds to the needs of its citizens will eventually create a democratic and good investment environment leading to economic and social growth.

Trade openness through exploiting comparative advantage, technology transfer and exposure to competition has a significant positive impact on economic performance $[9,10]$. A recent study analyzed the determinants of economic growth in Jordan by using a conventional model based on the aggregate Cobb Douglas production function with respect to labor, capital, exports, imports and dummy variables [1]. It found that real GDP growth rate has positive relationship with real capital growth and real export growth but it has negative relationship with labor size growth and real import growth. Therefore, it recommended to enhance export sector and to increase investment in human capital by raising labors' education level, skills and expertise in order to boost their productivities which eventually will increase economic growth. Razmi and Refaei also investigated the impact of economic freedom and trade openness on economic growth [40]. They estimated the economic growth model by using 17 Middle East and East Asian countries' data during 20002009. Their results showed that economic freedom index is positively and robustly correlated with growth. They also demonstrated that trade openness and economic freedom have significant positive relationship with growth. Furthermore, they decomposed the economic freedom index into the five categories constructing the index, and they observed that the indices of government size and access to sound money are negatively correlated with economic growth. Similarly, Lahouij used panel data for the time period 2002-2013 to test the impact of governance and other factors on the economic growth of some selected oilimporting MENA countries (Middle East and North Africa countries) [27]. It found that governance is strongly associated with the economic development.

Petrakos used different method by conducting a questionnaire survey to explore experts' views on the factors of economic growth [37]. They found that the most effective determinant of growth was political and institutional factors which have the prevailed effects on such growth in less advanced countries, while the parameters with more economic, hi-tech and specialized features strongly affect economic performance in advanced countries. Bayar also investigated the impact of six public governance indicators on the economic growth in the transitional economies of the European Union during the period 2002-2013 [5]. He found that all governance indicators except regulatory quality had a significant positive impact on economic growth; control of corruption and rule of law had the largest impact on economic growth, while political stability had the lowest impact. In addition, Edlund used panel data for 48 middleincome countries during the years of 2000 to 2014 in order to investigate the impact of economic freedom on the economic growth in middle-income countries [12]. It found that economic freedom is essential factor for economic growth. However, the components of economic freedom have different effects on economic growth. It also found that the legal system and property rights have significant positive effect on economic growth, while inflation has significant negative effect on it. Finally, Huchet-Bourdon used new measure for trade openness taking into account export quality and variety [19]. Based on the estimation of an endogenous growth model on a panel of 169 countries in the period of 1988-2014, it found a non-linear relationship between export variety, the export ratio and economic growth, suggesting that countries exporting higher quality products and new varieties grow more rapidly. 


\section{Data and Methodology}

\subsection{Data and Variables Description}

The study used annual data that comprises a representative sample of six OEAC, particularly Algeria, Kuwait, Oman, Bahrain, Saudi Arabia and United Arab Emirates, over the period of 1998-2017. The sample and the study period were dictated by data availability, noting that some OEAC face many political and economic problems in the last years, which lead to missing data for several years. The study used a panel data estimation technique because of its several advantages over both cross-section and time-series data sets; this technique has greater degrees of freedom and less multicollinearity leading to more efficient estimates and giving greater flexibility in modelling differences in behaviour across countries which enables to control for unobserved heterogeneity [18]. The data was extracted from World Bank databank which is calculated in a universal currency (US dollar) that is more stable than many other currencies and helps to achieve as much consistency as possible. The description of the variables according to the literature and the previous studies is as follows:

YG (dependent variable): the annual growth rate of real GDP as a proxy for economic growth, it is defined as the annual change in the production of goods and services in the economy. GDP is the market value of all finished goods and services produced within a country's borders in a specific time period and it is usually calculated on an annual basis. Economic growth is often influenced by various direct factors (e.g. human capital, natural resources, fixed capital and technological progress) and indirect factors (e.g. institutions, public polices, aggregate demand size and the efficiency of both financial system and government).

The independent variables are: KF: Gross fixed capital formation to GDP ratio as a proxy for annual gross fixed capital accumulation for a particular country that measures the value of acquisitions of new or existing assets by the private sector and government without deducting the depreciation of fixed assets. KF excludes land purchases, operating costs and financial assets. Countries need capital goods to replace the current assets that are used to produce goods and services, and if a country cannot replace capital goods, production declines. LF: labor force growth rate: it is a measure of the percentage change in an economy's labor force. Labor force is the number of people who are either employed or are actively looking for work, and they are at or above the working age of 16 . People not included in the labor force include those who do not want to work or can't work such as students, homemakers, disabled, incarcerated people and retirees. The economic theory stresses the positive effect of labor force growth rate on economic growth but the previous studies revealed contradictory results depending on the absorption capacity of each labor market. OT: Openness to trade as a proxy of economic policies that either restrict or invite trade between countries. Fewer restrictions on trade can foster economic trade, noting that trade tariffs, quotas and subsidies are examples of trade restrictions. Trade openness is measured by various ways but this study will depend on the sum of exports plus imports to the country's gross domestic product as its index, the higher the index the larger the influence of trade on domestic activities, and the stronger that country's economy. Exports mean the value of goods and services shipped to other countries. Exports help an economy to grow by creating employment, production and revenues, they also benefit all trading parties, present an opportunity to capture significant global market share, spread business risk by diversifying into multiple markets, reduce per-unit costs by expanding operations to meet increased demand, and allow the discovery of new technologies and marketing practices. On the other hand, imports mean the value of goods and services brought into the country from the rest of the world. If the value of a country's imports exceeds the value of its exports, its balance of trade will be negative. The country imports goods that its domestic industries can't produce as efficiently or cheaply as the exporting country, it may also import raw materials or intermediate goods that are not available within its borders. A reliance on imports under free trade agreements is responsible for a large portion of the decline in manufacturing jobs and for a reduced reliance on domestic goods. EF: Aggregate index for economic freedom is a proxy for the ability of members of a society to undertake economic actions or to protect their liberty to pursue their own economic interests, the higher the index the greater prosperity, well-being, and quality of life for the society. It measures the degree of freedom in investment, trade and business, it also assesses the degree of labor monetary and financial freedom, property rights etc. Classical theory has emphasized the significant role of free markets, free trade and free enterprises in economic growth.

Governance is defined as the way in which power is exercised in the management of a country's economic and social resources for development [47]. While United Nation defines it as the decision making's process and the process by which decisions are implemented or not implemented. The six Worldwide Governance Indicators and their definitions were obtained from World Bank Governance Indicators (WGI) and used as a proxy of governance. These indicators are based on 31 data sources reporting the perceptions of governance held by a large number of survey respondents and expert assessments worldwide. These indicators vary between -2.5 (weak) and 2.5 (strong) governance performance. Economic theory and the previous studies emphasized the positive impact of governance indicators on the economic growth. The definitions of such indicators are: 1- VA: Voice and Accountability measures the extent to which a country's citizens are able to participate in selecting their government, as well as freedom of expression, freedom of association, and a free media. 2- PS: Political Stability and Absence of Violence and Terrorism measure the likelihood that the government will be destabilized or overthrown by unconstitutional/violent means. 3- GE: Government Effectiveness measures the quality of public and civil services, the degree of its independence from political pressures, the quality of policy formulation and 
implementation, and the credibility of the government's commitment to such policies. 4- RQ: Regulatory Quality measures the ability of the government to formulate and implement sound policies and regulations that permit and promote private sector development. 5- RL: Rule of Law measures the extent to which agents have confidence in and abide by the rules of society, and in particular the quality of contract enforcement, property rights, police, courts, as well as the likelihood of crime and violence. 6- CC: Control of Corruption measures the extent to which public power is exercised for private gain, including both petty and grand forms of corruption, as well as capture of the state by elites and private interests.

$\mathrm{DM}$ is a dummy variable that indicates the absence or the presence of the Global Financial Crisis (GFC) of 2008 and its slow recovery afterwards. It takes the value one during the period 2008-2012, otherwise it takes the value zero. This crisis started to affect Arab countries' economies at the end of 2008 after the bankruptcy of Lehman Brothers Holdings Inc. The dummy variable was added to the model because GFC which is out of Arab countries' control may conceal or distort the expected positive impact of institutional reforms or the development in governance.

\subsection{Methodology}

This study starts with Cobb-Douglas production function which is widely used to represent the technological relationship between the amounts of two or more inputs, particularly physical capital and labour, and the amount of output that can be produced by those inputs. The CobbDouglas form was developed and tested against statistical evidence by Charles Cobb and Paul Douglas in 1928, and their important studies became the motive for many researchers to conduct vast number of studies both at individual and institutional levels in order to investigate the main determinants of economic growth: $\mathrm{Y}_{\mathrm{t}}=\mathrm{A}_{\mathrm{t}} \mathrm{K}_{\mathrm{t}}^{\alpha} \mathrm{L}_{\mathrm{t}}^{\beta}$

$\mathrm{Y}_{\mathrm{t}}$ : GDP at time $\mathrm{t}, \mathrm{K} \& \mathrm{~L}$ are capital and labor factors of production during the same period $t$, $A$ is total factor productivity or technological progress at the same time $t$. The above model could be extended as follows: $\mathrm{Y}_{\mathrm{t}}=\mathrm{A}_{\mathrm{t}} \mathrm{K}_{\mathrm{t}}^{\alpha} \mathrm{L}_{\mathrm{t}}^{\beta} \mathrm{O}_{\mathrm{t}}^{\varphi}$ $\mathrm{E}_{\mathrm{t}}^{\mathrm{E}}$

$\mathrm{O}$ is openness to trade at time t, $\mathrm{E}$ is economic freedom at time t, where $\alpha, \beta, \varphi, \in$ represent the output elasticity of capital, labor, trade openness and economic freedom respectively, because output or gross domestic product can be affected by these factors. After taking the logarithm of both sides of the above expression it becomes as follows:

Ln $\mathrm{Y}_{\mathrm{t}}=\ln \mathrm{A}_{\mathrm{t}}+\alpha \ln \mathrm{K}_{\mathrm{t}}+\beta \ln \mathrm{L}_{\mathrm{t}}+\varphi \ln \mathrm{O}_{\mathrm{t}}+C \ln \mathrm{E}_{\mathrm{t}}$ Then it can be estimated as follows:

Ln $Y_{t}=c+\alpha \ln K_{t}+\beta \ln L_{t}+\varphi \ln \mathrm{O}_{t}+\epsilon \ln E_{t}+e_{t}(c:$ constant/intercept, $\mathrm{e}_{\mathrm{t}}$ : error term)

Differentiating with respect to time both sides of the equation: $\operatorname{Ln} \mathrm{Y}_{\mathrm{t}}=\ln \mathrm{A}_{\mathrm{t}}+\alpha \ln \mathrm{K}_{\mathrm{t}}+\beta \ln \mathrm{L}_{\mathrm{t}}$ then it becomes as follows: $\mathrm{YG}_{\mathrm{t}}=\mathrm{AG}_{\mathrm{t}}+\alpha \mathrm{KG}_{\mathrm{t}}+\beta \mathrm{LG}_{\mathrm{t}}$

YG: the growth rate of real GDP at time t. AG: the growth rate of technological progress (total factor productivity or Solow residual). KG: the growth rate of capital stock at time $\mathrm{t}$, and it can be measured by the gross fixed capital formation to GDP ratio at time $\mathrm{t}$ as the previous studies did. LG: population or labor force growth rate at time t. It is known that the time derivative of the logarithm of any variable is the growth rate of that variable. The last equation can be estimated by the following regression model: $\mathrm{YG}_{\mathrm{t}}=\mathrm{C}+\alpha$ $\mathrm{KG}_{\mathrm{t}}+\beta \mathrm{LG}_{\mathrm{t}}+\mu_{\mathrm{t}}\left(\mathrm{C}\right.$ : constant/intercept, $\mu_{\mathrm{t}}$ : error term)

This study will depend on the previous explaining and follow the previous studies in order to estimate its model [4, $5,14,7,15,36,34,27,33,20,40,6]$. The regression model is:

$$
\begin{gathered}
\mathrm{YG}_{\mathrm{it}}=\alpha_{0}+\alpha_{1} \mathrm{KF}_{\mathrm{it}}+\alpha_{2} \mathrm{LF}_{\mathrm{it}}+\alpha_{3} \mathrm{OT}_{\mathrm{it}}+\alpha_{4} \mathrm{EF}_{\mathrm{it}}+\alpha_{5} \mathrm{VA}_{\mathrm{it}}+\alpha_{6} \\
\mathrm{PS}_{\mathrm{it}}+\alpha_{7} \mathrm{GE}_{\mathrm{it}}+\alpha_{8} \mathrm{RQ}_{\mathrm{it}}+\alpha_{9} \mathrm{RL}_{\mathrm{it}}+\alpha_{10} \mathrm{CC}_{\mathrm{it}}+\mu \mathrm{DM}_{\mathrm{it}}+\mathrm{U}_{\mathrm{it}}
\end{gathered}
$$

Where $\alpha_{0}$ represents the intercept, $\mathrm{i}$ represents country, $\mathrm{t}$ represents year, $U_{i t}$ represents random error term. YG represents growth rate of real GDP, KF represents gross fixed capital formation to GDP ratio, LF represents labor force growth rate, OT represents trade openness that is measured by the sum of exports and imports to GDP ratio, EF represents economic freedom aggregate index, VA: voice and accountability, PS: political stability, GE: government effectiveness, RQ: regulatory quality, RL: rule of law, CC: control of corruption, DM: a dummy variable that indicates the absence or the presence of GFC of 2008 and its slow recovery afterwards. The literature and the previous studies stressed that the higher level of public governance could stimulate domestic and foreign direct investments by reducing uncertainty, creating good investment environment which in turns increase economic growth. Therefore, the expected signs of all coefficients except that of DM are to be positive.

\section{Empirical Results}

The empirical results of estimating the model began with the unit root tests in Eviews 9. In order to avoid spurious relationship, the study used Levin, Lin \& Chu, Im, Pesaran and Shin W-stat, ADF - Fisher Chi-square, PP - Fisher Chisquare and Breitung t-stat to test for the existence of unit roots in the panel data. Tables 1 and 2 present testing of the null hypothesis of existing unit root for the study variables at both individual effects level and individual effects and individual linear trends level respectively. The null hypothesis for these tests: panel data has a unit root (nonstationary). If the probability value is less than $5 \%$, the null hypothesis will be rejected meaning that the variable is stationary at this level, but if it is more than $5 \%$, the null hypothesis can't be rejected, meaning that the variable is not stationary at this level. If the results are mixed, the decision will be taken based on the majority of the test methods' results. According to tables 1 and 2, the variables KF, OT, $\mathrm{RL}, \mathrm{GE}$ and $\mathrm{CC}$ are not stationary at both the level of individual effects and the level of individual effects and individual linear trends, because the majority of the probability values for unit root test methods are more than $5 \%$ for these variables at both levels. Meanwhile, VA and PS are not stationary at the level of individual effects but they 
are stationary at the level of individual effects and individual linear trends. In contrast, RQ is stationary at the level of individual effects but not stationary at the level of individual effects and individual linear trends, while YG, LF, and EF are stationary at both levels because the majority of the probability values for unit root test methods are less than $5 \%$ for these variables at these levels.

Table 1. Panel unit root test: Level of individual effects.

\begin{tabular}{|c|c|c|c|c|c|}
\hline Variable & Exogenous variables & Method & Statistic value & Prob. value & decision \\
\hline \multirow{4}{*}{ YG } & \multirow{4}{*}{ Individual effects } & Levin, Lin \& Chu & -3.36474 & 0.0004 & Stationary \\
\hline & & IM, Pesaran and Shin W-stat & -2.61564 & 0.0045 & Stationary \\
\hline & & ADF-Fisher Chi-square & 26.5338 & 0.0090 & Stationary \\
\hline & & PP- Fisher Chi-square & 38.0949 & 0.0001 & Stationary \\
\hline \multirow{3}{*}{$\mathrm{LF}$} & \multirow{3}{*}{ Individual effects } & Levin, Lin \& Chu & -1.97642 & 0.0241 & Stationary \\
\hline & & IM, Pesaran and Shin W-stat & -1.76026 & 0.0392 & Stationary \\
\hline & & ADF-Fisher Chi-square & 19.2288 & 0.0832 & Non Stationary \\
\hline \multirow{4}{*}{ KF } & \multirow{4}{*}{ Individual effects } & Levin, Lin \& Chu & 0.88035 & 0.8107 & Non stationary \\
\hline & & IM, Pesaran and Shin W-stat & 0.75777 & 0.7757 & Non Stationary \\
\hline & & ADF-Fisher Chi-square & 10.7240 & 0.5527 & Non Stationary \\
\hline & & PP- Fisher Chi-square & 11.2669 & 0.5062 & Non Stationary \\
\hline \multirow{4}{*}{$\mathrm{EF}$} & \multirow{4}{*}{ Individual effects } & Levin, Lin \& Chu & -2.71914 & 0.0033 & Stationary \\
\hline & & IM, Pesaran and Shin W-stat & -1.89996 & 0.0287 & Stationary \\
\hline & & ADF-Fisher Chi-square & 22.6599 & 0.0308 & Stationary \\
\hline & & PP- Fisher Chi-square & 18.8861 & 0.0913 & Non Stationary \\
\hline \multirow{3}{*}{ OT } & \multirow{3}{*}{ Individual effects } & IM, Pesaran and Shin W-stat & 0.07898 & 0.5315 & Non Stationary \\
\hline & & ADF-Fisher Chi-square & 12.7687 & 0.3861 & Non Stationary \\
\hline & & PP- Fisher Chi-square & 12.0226 & 0.4439 & Non Stationary \\
\hline \multirow{4}{*}{ VA } & \multirow{4}{*}{ Individual effects } & Levin, Lin \& Chu & -1.68329 & 0.0462 & Stationary \\
\hline & & IM, Pesaran and Shin W-stat & 0.23455 & 0.5927 & Non Stationary \\
\hline & & ADF-Fisher Chi-square & 8.42415 & 0.7512 & Non Stationary \\
\hline & & PP- Fisher Chi-square & 6.51019 & 0.8882 & Non Stationary \\
\hline \multirow{4}{*}{ GE } & \multirow{4}{*}{ Individual effects } & Levin, Lin \& Chu & 0.25340 & 0.6000 & Non Stationary \\
\hline & & IM, Pesaran and Shin W-stat & 0.19940 & 0.5790 & Non Stationary \\
\hline & & ADF-Fisher Chi-square & 25.5599 & 0.0124 & Stationary \\
\hline & & PP- Fisher Chi-square & 26.0642 & 0.0105 & Stationary \\
\hline \multirow{4}{*}{ PS } & \multirow{4}{*}{ Individual effects } & Levin, Lin \& Chu & -0.32140 & 0.3740 & Non Stationary \\
\hline & & IM, Pesaran and Shin W-stat & -0.56103 & 0.2874 & Non Stationary \\
\hline & & ADF-Fisher Chi-square & 15.5962 & 0.2104 & Non Stationary \\
\hline & & PP- Fisher Chi-square & 19.4217 & 0.0788 & Non Stationary \\
\hline \multirow{2}{*}{ RQ } & \multirow{2}{*}{ Individual effects } & ADF-Fisher Chi-square & 21.2819 & 0.0464 & Stationary \\
\hline & & PP- Fisher Chi-square & 16.2255 & 0.1811 & Non Stationary \\
\hline \multirow{4}{*}{$\mathrm{RL}$} & \multirow{4}{*}{ Individual effects } & Levin, Lin \& Chu & 0.35495 & 0.6387 & Non Stationary \\
\hline & & IM, Pesaran and Shin W-stat & 0.59720 & 0.7248 & Non Stationary \\
\hline & & ADF-Fisher Chi-square & 24.8928 & 0.0153 & Stationary \\
\hline & & PP- Fisher Chi-square & 21.1772 & 0.0478 & Stationary \\
\hline \multirow{4}{*}{$\mathrm{CC}$} & \multirow{4}{*}{ Individual effects } & Levin, Lin \& Chu & -1.18242 & 0.1185 & Non Stationary \\
\hline & & IM, Pesaran and Shin W-stat & -0.73531 & 0.2311 & Non Stationary \\
\hline & & ADF-Fisher Chi-square & 16.1250 & 0.1856 & Non Stationary \\
\hline & & PP- Fisher Chi-square & 15.6582 & 0.2074 & Non Stationary \\
\hline
\end{tabular}

Source: Author calculation using Eviews.

Table 2. Panel unit root test: Level of individual effects and individual linear trends.

\begin{tabular}{|c|c|c|c|c|c|}
\hline Variable & Exogenous variables & Method & Statistic value & Prob. value & decision \\
\hline \multirow{4}{*}{ YG } & \multirow{4}{*}{ Individual effects \& individual linear trends } & Levin, Lin \& Chu & -4.67357 & 0.0000 & Stationary \\
\hline & & Breitung t-stat & -4.17666 & 0.0000 & Stationary \\
\hline & & IM, Pesaran and Shin W-stat & -2.69529 & 0.0035 & Stationary \\
\hline & & PP- Fisher Chi-square & 27.7924 & 0.0059 & Stationary \\
\hline \multirow{4}{*}{ LF } & \multirow{4}{*}{ Individual effects \& individual linear trends } & Levin, Lin \& Chu & -2.10559 & 0.0176 & Stationary \\
\hline & & Breitung t-stat & 3.09642 & 0.9990 & Non Stationary \\
\hline & & ADF-Fisher Chi-square & 30.4038 & 0.0024 & Stationary \\
\hline & & PP- Fisher Chi-square & 23.5784 & 0.0232 & Stationary \\
\hline KF & Individual effects \& individual linear trends & Levin, Lin \& Chu & -0.79387 & 0.2136 & Non Stationary \\
\hline
\end{tabular}




\begin{tabular}{|c|c|c|c|c|c|}
\hline Variable & Exogenous variables & Method & Statistic value & Prob. value & decision \\
\hline \multirow{9}{*}{$\mathrm{EF}$} & \multirow{9}{*}{ Individual effects \& individual linear trends } & Breitung t-stat & -0.19168 & 0.4240 & Non Stationary \\
\hline & & IM, Pesaran and Shin W-stat & -2.39263 & 0.0084 & Stationary \\
\hline & & ADF-Fisher Chi-square & 25.1419 & 0.0142 & Stationary \\
\hline & & PP- Fisher Chi-square & 14.5235 & 0.2685 & Non Stationary \\
\hline & & Levin, Lin \& Chu & -1.77080 & 0.0383 & Stationary \\
\hline & & Breitung t-stat & -1.73856 & 0.0411 & Stationary \\
\hline & & IM, Pesaran and Shin W-stat & -1.95791 & 0.0251 & Stationary \\
\hline & & ADF-Fisher Chi-square & 21.2591 & 0.0467 & Stationary \\
\hline & & PP- Fisher Chi-square & 19.4528 & 0.0782 & Non Stationary \\
\hline \multirow{5}{*}{ OT } & \multirow{5}{*}{ Individual effects \& individual linear trends } & Levin, Lin \& Chu & -1.21800 & 0.1116 & Non Stationary \\
\hline & & Breitung t-stat & 1.27780 & 0.8993 & Non Stationary \\
\hline & & IM, Pesaran and Shin W-stat & -1.09468 & 0.1368 & Non Stationary \\
\hline & & ADF-Fisher Chi-square & 18.3726 & 0.1048 & Non Stationary \\
\hline & & PP- Fisher Chi-square & 30.0051 & 0.0028 & Stationary \\
\hline \multirow{5}{*}{ VA } & \multirow{5}{*}{ Individual effects \& individual linear trends } & Levin, Lin \& Chu & -3.69505 & 0.0001 & Stationary \\
\hline & & Breitung t-stat & -3.02633 & 0.0012 & Stationary \\
\hline & & IM, Pesaran and Shin W-stat & -1.82263 & 0.0342 & Stationary \\
\hline & & ADF-Fisher Chi-square & 19.5661 & 0.0758 & Non Stationary \\
\hline & & PP- Fisher Chi-square & 15.0586 & 0.2382 & Non Stationary \\
\hline \multirow{5}{*}{ GE } & \multirow{5}{*}{ Individual effects \& individual linear trends } & Levin, Lin \& Chu & -0.82818 & 0.2038 & Non Stationary \\
\hline & & Breitung t-stat & 2.60578 & 0.9954 & Non Stationary \\
\hline & & IM, Pesaran and Shin W-stat & -0.37713 & 0.3530 & Non Stationary \\
\hline & & ADF-Fisher Chi-square & 20.6595 & 0.0556 & Non Stationary \\
\hline & & PP- Fisher Chi-square & 28.9035 & 0.0041 & Stationary \\
\hline \multirow{5}{*}{ PS } & \multirow{5}{*}{ Individual effects \& individual linear trends } & Levin, Lin \& Chu & -2.64391 & 0.0041 & Stationary \\
\hline & & Breitung t-stat & -2.17074 & 0.0150 & Stationary \\
\hline & & IM, Pesaran and Shin W-stat & -2.60731 & 0.0046 & Stationary \\
\hline & & ADF-Fisher Chi-square & 27.5734 & 0.0064 & Stationary \\
\hline & & PP- Fisher Chi-square & 32.1415 & 0.0013 & Stationary \\
\hline \multirow{5}{*}{ RQ } & \multirow{5}{*}{ Individual effects \& individual linear trends } & Levin, Lin \& Chu & -2.10886 & 0.0175 & Stationary \\
\hline & & Breitung t-stat & -0.30061 & 0.3819 & Non Stationary \\
\hline & & IM, Pesaran and Shin W-stat & -0.54663 & 0.2923 & Non Stationary \\
\hline & & ADF-Fisher Chi-square & 14.9167 & 0.2460 & Non Stationary \\
\hline & & PP- Fisher Chi-square & 6.98715 & 0.8585 & Non Stationary \\
\hline \multirow{5}{*}{ RL } & \multirow{5}{*}{ Individual effects \& individual linear trends } & Levin, Lin \& Chu & 1.62415 & 0.9478 & Non Stationary \\
\hline & & Breitung t-stat & 0.89860 & 0.8156 & Non Stationary \\
\hline & & IM, Pesaran and Shin W-stat & 2.83798 & 0.9977 & Non Stationary \\
\hline & & ADF-Fisher Chi-square & 10.2319 & 0.5956 & Non Stationary \\
\hline & & PP- Fisher Chi-square & 13.2544 & 0.3508 & Non Stationary \\
\hline \multirow{5}{*}{$\mathrm{CC}$} & \multirow{5}{*}{ Individual effects \& individual linear trends } & Levin, Lin \& Chu & -0.41367 & 0.3396 & Non Stationary \\
\hline & & Breitung t-stat & -0.57518 & 0.2826 & Non Stationary \\
\hline & & IM, Pesaran and Shin W-stat & -1.15994 & 0.1230 & Non Stationary \\
\hline & & ADF-Fisher Chi-square & 17.2936 & 0.1389 & Non Stationary \\
\hline & & PP- Fisher Chi-square & 20.5278 & 0.0577 & Non Stationary \\
\hline
\end{tabular}

Source: Author calculation using Eviews.

After taking the first difference for the variables KF, OT, RL, GE, VA, PS, RQ and CC they became stationary at both levels as illustrated in tables 3 and 4 .

Table 3. Panel unit root test: first difference with individual effects.

\begin{tabular}{|c|c|c|c|c|c|}
\hline Variable & Exogenous variables & Method & Statistic value & Prob. value & decision \\
\hline \multirow{4}{*}{$\mathrm{D}(\mathrm{OT})$} & \multirow{4}{*}{ Individual effects } & Levin, Lin \& Chu & -7.39651 & 0.0000 & Stationary \\
\hline & & IM, Pesaran and Shin W-stat & -5.80189 & 0.0000 & Stationary \\
\hline & & ADF-Fisher Chi-square & 54.7597 & 0.0000 & Stationary \\
\hline & & PP- Fisher Chi-square & 59.6365 & 0.0000 & Stationary \\
\hline \multirow{3}{*}{$\mathrm{D}(\mathrm{KF})$} & \multirow{3}{*}{ Individual effects } & Levin, Lin \& Chu & -3.93538 & 0.0000 & Stationary \\
\hline & & IM, Pesaran and Shin W-stat & -5.11409 & 0.0000 & Stationary \\
\hline & & ADF-Fisher Chi-square & 47.9325 & 0.0000 & Stationary \\
\hline \multirow{4}{*}{$\mathrm{D}(\mathrm{VA})$} & \multirow{4}{*}{ Individual effects } & Levin, Lin \& Chu & -7.04281 & 0.0000 & Stationary \\
\hline & & IM, Pesaran and Shin W-stat & -5.83607 & 0.0000 & Stationary \\
\hline & & ADF-Fisher Chi-square & 54.1640 & 0.0000 & Stationary \\
\hline & & PP- Fisher Chi-square & 112.072 & 0.0000 & Stationary \\
\hline \multirow{2}{*}{ D (PS) } & \multirow{2}{*}{ Individual effects } & Levin, Lin \& Chu & -10.3202 & 0.0000 & Stationary \\
\hline & & IM, Pesaran and Shin W-stat & -9.57937 & 0.0000 & Stationary \\
\hline
\end{tabular}




\begin{tabular}{|c|c|c|c|c|c|}
\hline Variable & Exogenous variables & Method & Statistic value & Prob. value & decision \\
\hline \multirow{6}{*}{$\mathrm{D}(\mathrm{RQ})$} & \multirow{6}{*}{ Individual effects } & ADF-Fisher Chi-square & 86.6516 & 0.0000 & Stationary \\
\hline & & PP- Fisher Chi-square & 189.049 & 0.0000 & Stationary \\
\hline & & Levin, Lin \& Chu & -6.91521 & 0.0000 & Stationary \\
\hline & & IM, Pesaran and Shin W-stat & -6.07667 & 0.0000 & Stationary \\
\hline & & ADF-Fisher Chi-square & 58.1369 & 0.0000 & Stationary \\
\hline & & PP- Fisher Chi-square & 67.2236 & 0.0000 & Stationary \\
\hline \multirow{4}{*}{$\mathrm{D}(\mathrm{RL})$} & \multirow{4}{*}{ Individual effects } & Levin, Lin \& Chu & -2.28857 & 0.0111 & Stationary \\
\hline & & IM, Pesaran and Shin W-stat & -1.39626 & 0.0813 & Non Stationary \\
\hline & & ADF-Fisher Chi-square & 35.2145 & 0.0004 & Stationary \\
\hline & & PP- Fisher Chi-square & 170.492 & 0.0000 & Stationary \\
\hline \multirow{4}{*}{$\mathrm{D}(\mathrm{GE})$} & \multirow{4}{*}{ Individual effects } & Levin, Lin \& Chu & -2.92508 & 0.0017 & Stationary \\
\hline & & IM, Pesaran and Shin W-stat & -4.75514 & 0.0000 & Stationary \\
\hline & & ADF-Fisher Chi-square & 45.0467 & 0.0000 & Stationary \\
\hline & & PP- Fisher Chi-square & 114.210 & 0.0000 & Stationary \\
\hline \multirow{4}{*}{$\mathrm{D}(\mathrm{CC})$} & \multirow{4}{*}{ Individual effects } & Levin, Lin \& Chu & -8.36924 & 0.0000 & Stationary \\
\hline & & IM, Pesaran and Shin W-stat & -7.19741 & 0.0000 & Stationary \\
\hline & & ADF-Fisher Chi-square & 65.6563 & 0.0000 & Stationary \\
\hline & & PP- Fisher Chi-square & 213.190 & 0.0000 & Stationary \\
\hline
\end{tabular}

Source: Author calculation using Eviews.

Table 4. Panel unit root test: first difference with individual effects and individual linear trends.

\begin{tabular}{|c|c|c|c|c|c|}
\hline Variable & Exogenous variables & Method & Statistic value & Prob. value & decision \\
\hline \multirow{5}{*}{$\mathrm{D}(\mathrm{OT})$} & \multirow{5}{*}{$\begin{array}{l}\text { Individual effects \& individual } \\
\text { linear trends }\end{array}$} & Levin, Lin \& Chu & -7.92388 & 0.0000 & Stationary \\
\hline & & Breitung t-stat & -2.85405 & 0.0022 & Stationary \\
\hline & & IM, Pesaran and Shin W-stat & -4.37364 & 0.0000 & Stationary \\
\hline & & ADF-Fisher Chi-square & 41.5939 & 0.0000 & Stationary \\
\hline & & PP- Fisher Chi-square & 54.6743 & 0.0000 & Stationary \\
\hline \multirow{4}{*}{$\mathrm{D}(\mathrm{KF})$} & \multirow{4}{*}{$\begin{array}{l}\text { Individual effects \& individual } \\
\text { linear trends }\end{array}$} & Levin, Lin \& Chu & -5.12770 & 0.0000 & Stationary \\
\hline & & Breitung t-stat & -3.21090 & 0.0007 & Stationary \\
\hline & & ADF-Fisher Chi-square & 41.7115 & 0.0000 & Stationary \\
\hline & & PP- Fisher Chi-square & 53.8144 & 0.0000 & Stationary \\
\hline \multirow{5}{*}{$\mathrm{D}(\mathrm{VA})$} & \multirow{5}{*}{$\begin{array}{l}\text { Individual effects \& individual } \\
\text { linear trends }\end{array}$} & Levin, Lin \& Chu & -5.70854 & 0.0000 & Stationary \\
\hline & & Breitung t-stat & -6.49315 & 0.0000 & Stationary \\
\hline & & IM, Pesaran and Shin W-stat & -4.05304 & 0.0000 & Stationary \\
\hline & & ADF-Fisher Chi-square & 37.3732 & 0.0002 & Stationary \\
\hline & & PP- Fisher Chi-square & 77.2358 & 0.0000 & Stationary \\
\hline \multirow{4}{*}{ D (PS) } & \multirow{4}{*}{$\begin{array}{l}\text { Individual effects \& individual } \\
\text { linear trends }\end{array}$} & Levin, Lin \& Chu & -8.74833 & 0.0000 & Stationary \\
\hline & & IM, Pesaran and Shin W-stat & -7.97408 & 0.0000 & Stationary \\
\hline & & ADF-Fisher Chi-square & 66.1621 & 0.0000 & Stationary \\
\hline & & PP- Fisher Chi-square & 77.6696 & 0.0000 & Stationary \\
\hline \multirow{5}{*}{$\mathrm{D}(\mathrm{RQ})$} & \multirow{5}{*}{$\begin{array}{l}\text { Individual effects \& individual } \\
\text { linear trends }\end{array}$} & Levin, Lin \& Chu & -6.77658 & 0.0000 & Stationary \\
\hline & & Breitung t-stat & -6.24148 & 0.0000 & Stationary \\
\hline & & IM, Pesaran and Shin W-stat & -6.32854 & 0.0000 & Stationary \\
\hline & & ADF-Fisher Chi-square & 52.7630 & 0.0000 & Stationary \\
\hline & & PP- Fisher Chi-square & 71.7090 & 0.0000 & Stationary \\
\hline \multirow{5}{*}{$\mathrm{D}(\mathrm{RL})$} & \multirow{5}{*}{$\begin{array}{l}\text { Individual effects \& individual } \\
\text { linear trends }\end{array}$} & Levin, Lin \& Chu & -2.98169 & 0.0014 & Stationary \\
\hline & & Breitung t-stat & -0.45125 & 0.3259 & Non Stationary \\
\hline & & IM, Pesaran and Shin W-stat & -1.20981 & 0.1132 & Non Stationary \\
\hline & & ADF-Fisher Chi-square & 31.6014 & 0.0016 & Stationary \\
\hline & & PP- Fisher Chi-square & 44.2765 & 0.0000 & Stationary \\
\hline \multirow{3}{*}{$\mathrm{D}(\mathrm{GE})$} & \multirow{3}{*}{$\begin{array}{l}\text { Individual effects \& individual } \\
\text { linear trends }\end{array}$} & Levin, Lin \& Chu & -7.53409 & 0.0000 & Stationary \\
\hline & & Breitung t-stat & -3.71289 & 0.0001 & Stationary \\
\hline & & PP- Fisher Chi-square & 92.4853 & 0.0000 & Stationary \\
\hline \multirow{5}{*}{$\mathrm{D}(\mathrm{CC})$} & \multirow{5}{*}{$\begin{array}{l}\text { Individual effects \& individual } \\
\text { linear trends }\end{array}$} & Levin, Lin \& Chu & -9.01753 & 0.0000 & Stationary \\
\hline & & Breitung t-stat & -8.47049 & 0.0000 & Stationary \\
\hline & & IM, Pesaran and Shin W-stat & -7.64629 & 0.0000 & Stationary \\
\hline & & ADF-Fisher Chi-square & 62.8447 & 0.0000 & Stationary \\
\hline & & PP- Fisher Chi-square & 73.8873 & 0.0000 & Stationary \\
\hline
\end{tabular}

Source: Author calculation using Eviews.

The study used Pedroni panel cointegration test (Engle-Granger based) in which seven test types with eleven probability 
values should be taken into consideration. The null hypothesis for this cointegration test is that there is no cointegration in the model. The results of applying this test are shown in tables 5 and 6, noting that six of eleven outcomes (majority) are significant in both cases of individual intercept and individual intercept and individual trend. Therefore, the null hypothesis is rejected indicating that the model is cointegrated.

Table 5. Pedroni Residual Cointegration Test (individual intercept).

\begin{tabular}{lllll}
\hline & Statistic & Prob. & Weighted statistic & Prob. \\
\hline Panel v-Statistic & -1.846691 & 0.9676 & -2.224428 & 0.9869 \\
Panel rho-Statistic & 1.760863 & 0.9609 & 1.384695 & 0.9169 \\
Panel PP-Statistic & -3.072311 & 0.0011 & -7.097322 & 0.0000 \\
Panel ADF-Statistic & -2.188634 & 0.0143 & -3.781657 & 0.0001 \\
Group rho-Statistic & 2.393296 & 0.9917 & & \\
Group PP-Statistic & -8.338913 & 0.0000 & & \\
Group ADF-Statistic & -5.027986 & 0.0000 & & \\
\hline
\end{tabular}

Source: Author calculation using Eviews.

Table 6. Pedroni Residual Cointegration Test (individual intercept and individual trend).

\begin{tabular}{|c|c|c|c|c|}
\hline & Statistic & Prob. & Weighted statistic & Prob. \\
\hline Panel v-Statistic & -2.892731 & 0.9981 & -3.232929 & 0.9994 \\
\hline Panel rho-Statistic & 2.779377 & 0.9973 & 2.280839 & 0.9887 \\
\hline Panel PP-Statistic & -2.336265 & 0.0097 & -6.095702 & 0.0000 \\
\hline Panel ADF-Statistic & -1.750026 & 0.0401 & -4.612917 & 0.0000 \\
\hline Group rho-Statistic & 3.314802 & 0.9995 & & \\
\hline Group PP-Statistic & -6.575011 & 0.0000 & & \\
\hline Group ADF-Statistic & -4.742640 & 0.0000 & & \\
\hline
\end{tabular}

Source: Author calculation using Eviews.

Based on the previous results, Fully Modified OLS (FMOLS) was used for estimation. FMOLS was originally designed by Phillips and Hansen to provide optimal unbiased estimates of cointegrating regressions [38]. This method had modified least squares to account for serial correlation and for endogeneity in the regressors. The result of FMOLS estimation method is presented in table 7 which revealed that all independent variables' coefficients carry the correct expected signs which are consistent with the economic theory and most previous studies. GFC of 2008 (DM) has a significant negative effect (at $1 \%$ significance level) on the economic growth of OEAC by about $1.35 \%$. The most effective factors (at $1 \%$ significance level) are government effectiveness, rule of law then regulatory quality. A $1 \%$ increase in government effectiveness increases the growth rate of real GDP of these countries by about $8.82 \%$, while a $1 \%$ increase in the rule of law increases their real GDP growth rate by about $8.54 \%$. An increase in regulatory quality by $1 \%$ can result in $6.54 \%$ increase in economic growth of such countries, while trade openness, control of corruption, political stability and voice and accountability have insignificant positive impacts on their economic growth during the study period. Labor force growth rate has higher effect on their economic growth than fixed capital accumulation (at $10 \%$ significance level), meaning that a $1 \%$ increase in LF increases their growth rate of real GDP by about $0.33 \%$, while a $1 \%$ increase in KF increases their economic growth by about $0.07 \%$. Economic freedom significantly contributes to higher economic growth in these countries, meaning that a $1 \%$ increase in economic freedom (EF) increases their economic growth by about $0.38 \%$ at $1 \%$ significance level. Based on the previous analysis, the null hypothesis is rejected.
Table 7. Results of estimation using FMOLS.

\begin{tabular}{lllll}
\hline Variable & Coefficient & Std. Error & t-Statistic & Prob. \\
\hline KF & 0.070993 & 0.041693 & 1.702734 & 0.0923 \\
LF & 0.328647 & 0.179183 & 1.834145 & 0.0701 \\
EF & 0.380095 & 0.074171 & 5.124600 & 0.0000 \\
OT & 0.004016 & 0.011858 & 0.338650 & 0.7357 \\
VA & 2.555587 & 1.558004 & 1.640295 & 0.1046 \\
PS & 0.357953 & 0.715298 & 0.500425 & 0.6181 \\
RQ & 6.540325 & 0.952980 & 6.863024 & 0.0000 \\
GE & 8.817469 & 1.538970 & 5.729461 & 0.0000 \\
RL & 8.536172 & 1.704568 & 5.007821 & 0.0000 \\
CC & 0.779067 & 0.749717 & 1.039149 & 0.3017 \\
DM & -1.349655 & 0.502455 & -2.686119 & 0.0087 \\
\hline
\end{tabular}

Source: Authors' calculations using Eviews.

KF: gross fixed capital formation, LF: labor force growth rate, OT: openness to trade, EF: economic freedom, VA: voice and accountability, PS: political stability, GE: government effectiveness, RQ: regulatory quality, CC: control of corruption, and RL: rule of law, DM: dummy variable.

The low and insignificant coefficient of trade openness can be explained by the heavily dependence of the revenues of OEAC on exporting natural raw materials (oil) and the great reliance on importing final or consumer goods under free trade agreements, which are responsible for a large portion of the decline in manufacturing jobs or production sectors and hence slow economic growth. Some studies found that the quality and the variation of exports matter; trade openness could have a negative effect on economic growth when the country specializes in low quality products and whesn it has low variety of exports [19]. Two studies also affirmed that the positive impact of trade openness on economic growth is conditional upon the presence of international knowledge spillover, without which trade liberalization could negatively affect economic growth $[35,40]$. The structural characteristics 
of developing countries also could reverse the terms of trade to their disadvantages [45].

\section{Conclusions and Recommendations}

The main goal of this study is to identify the most effective factors on economic growth of OEAC during the period 1998-2017. Some study variables were stationary at level and the others were not. Therefore, Pedroni cointegration tests were conducted indicating that the model is cointegrated. FMOLS estimation revealed the most effective determinants of economic growth of OEAC during the study period which are: government effectiveness, rule of law then regulatory quality. In general, improving the business climate in Arab countries is very important in attracting both national and international investments which will ultimately boost their economic growth. Actually, good governance has been affirmed as a conditionality for being legible to most external aid by the World Bank and International Monetary Fund [34, 26]. Countries also can obtain higher credit ratings when they have good and effective public administration and better governance, which can reduce the cost of capital and improve their economic performance. The traditional determinants of economic growth can't positively impact the economic performance if there is underdeveloped, instable, highly corrupted and untrustworthy institutional environment [11]. An important conclusion is derived from this study: the political and institutional aspects of the country (alongside conventional economic determinants of growth) can play a vital role in its economic growth. In addition, policy priorities are different between developed and developing countries, although there are some basic factors which are important and needed for economic growth independent of the level of development an economy exhibits, e.g. the result of this study found that voice and accountability is not significant at all, implying that this factor has a second priority in OEAC, while attracting domestic and foreign investments, increasing labor and capital productivities, strengthening governance, improving public administration and eradication of corruption have the first priorities in such oil-rich countries. OEAC need better administration and stronger governance to ensure resources are efficiently and effectively applied in pursuit of growth of their economies.

OEACs' governments should make "real" institutional reforms and adopt the appropriate polices that eliminate corruption and rent seeking behaviour and enhance the rule of law, which eventually will ensure resources are efficiently and effectively allocated. They also need to improve the quality of education and concentrate on developing the skills and expertise of their labor force. In addition, they have to establish specialization in the production of goods in which they have comparative advantages and diversify their production and sources of national income, and not to depend only on exporting natural raw materials. They also should facilitate international trade that allows transition of new knowledge and leading technologies, increases labor and capital productivities, encourages domestic and international competition, and attracts more international financial flows and foreign direct investments which will ultimately foster their economic growth and social development.

\section{References}

[1] AL-Raimony, A. (2011). The Determinants of Economic Growth in Jordan. Abhath Al-Yarmouk, Humanities and Social Sciences Series, 27 (3), 2297-2305.

[2] Barro, R. (1991). Economic Growth in a Cross Section of Countries. Quarterly Journal of Economics, 106 (2), 407-443.

[3] Barro, R. (1996). Determinants of Economic Growth: A Cross Country Empirical Study. National Bureau Of Economic Research (NBER), Working Paper 5698, 1050 Massachusetts Avenue Cambridge, MA 02138.

[4] Bayar, Y. (2016a). Impact of Openness and Economic Freedom on Economic Growth in the Transition Economies of the European Union. South-Eastern Europe Journal of Economics 1, 7-19.

[5] Bayar, Y. (2016b). Public Governance and Economic Growth in the Transitional Economies of the European Union. Transylvanian Review of Administrative sciences, No. 48, 5-18.

[6] Berggren, N. and Jordahl, H. (2005). Does Free Trade Really Reduce Growth? Further Testing Using The Economic Freedom Index. Public Choice, 122 (1-2), 99-114.

[7] Bouoiyour, J. and Naimbayel, D. (2012) Economic Growth in Sub-Saharan Africa: Is Governance a Source of Inequality between Countries?. paper presented at the 17th Annual Conference of the African Uganda Econometric Society.

[8] Brunetti, A., Kisunko G. and Weder, B. (1998). Credibility of Rules and Economic Growth: Evidence from a Worldwide Survey of the Private Sector. The World Bank Economic Review, 12 (3), 353-384.

[9] Dollar, D. and Kraay, A. (2000). Trade, Growth and Poverty. The World Bank Development Research Group, Washington, (mimeo).

[10] Dollar, D. (1992). Outward-Oriented Developing Economies Really Do Grow More Rapidly: Evidence from 95 LDCs, 1976-1985. Economic Development and Cultural Change, 40 (3), 523-544.

[11] Easterly, W. (2001). The elusive quest for growth: economists' adventures and misadventures in the topics. Cambridge MA: MIT Press.

[12] Edlund, K. (2017). Does economic freedom affect the growth rate? Evidence from middle-income countries. Bachelor thesis, International Business Program. http://www.divaportal.org/smash/get/diva2:1134907/FULLTE XT01.pdf

[13] Emara, N. and Chiu, I. (2016). The Impact of Governance on Economic Growth: The Case of Middle Eastern and North African Countries. Topics in Middle Eastern and African Economies, 18 (1), 126-144.

[14] Emara, N. and Jhonsa, E. (2014). Governance and Economic Growth: The Case of Middle East and North African Countries. Journal of Development and Economic Policies, 16 (1), 47-71. 
[15] Fayissa, B. and Nsiah, C. (2013). The Impact of Governance on Economic Growth in Africa. Journal of Developing Areas, 47 (1), 91-108.

[16] Granovetter, M. (1985). Economic Action and Social Structure: The Problem of Embeddedness. American Journal of Sociology, 91 (3), 481-510.

[17] Hall, R. and Jones, C. (1999). Why Do Some Countries Produce so Much More Output per Worker Than Others? Quarterly Journal of Economics, 114 (1), 83-116.

[18] Hsiao, c. (2003). Analysis of Panel Data. $2^{\text {nd }}$ edition, United Kingdom: Cambridge University Press.

[19] Huchet-Bourdon, M., Le Mouel, C. and Vijil, M. (2018). The relationship between trade openness and economic growth: Some new insights on the openness measurement issue. Wiley, the world economy, 41: 59-76.

[20] Josheski, D., Lazarov, D., and Koteski, C. (2011). CobbDouglas production function revisited, VAR and VECM analysis and a note on Fischer/Cobb-Douglass paradox. Munich Personal RePEc Archive. https://mpra.ub.unimuenchen.de/33576/, 1-22.

[21] Jutting, J. (2003). Institutions and Development: A Critical Review. OECD Development Center, Working Paper 210.

[22] Kandenge, F. (2006). Public and Private Investment and Economic Growth in Namibia (1970-2005). Botswana Journal of Economics. https://www.ajol.info/index.php/\%EE\%80\%80boje\%EE\%80 $\% 81 /$ article/viewFile/64200/51995

[23] Kindleberger, Charles p. (1965). Economic development. $2^{\text {nd }}$ edition, New York: McGraw-Hill.

[24] Knack, S. \& Keefer, P. (1997). Does social capital have an economic impact? A cross-country investigation. Quarterly Journal of Economics, 112 (4), 1251-1288.

[25] Kormendi, R. \& Meguire, P. (1985). Macroeconomic determinants of growth: cross-country Evidence. Journal of Monetary Economics, 16 (4), 141-163.

[26] Kurtz, J. and Schrank, A. (2007). Growth and Governance: Models, Measures, and Mechanisms. Journal of politics, 69 (2), 538-554.

[27] Lahouij, H. (2016). Does Governance Matter to Economic Growth? Evidence from MENA Countries. Awards for Excellence in Student Research and Creative Activity Documents. 5.

http://thekeep.eiu.edu/lib_awards_2016_docs/5.

[28] Lensink, R. (2001). Financial development, uncertainty and economic growth. De Economist, 149 (3), 299-312.

[29] Lensink, W. and Morrissey, O. (2006). Foreign Direct Investment: Flows, Volatility and the Impact on Growth. Review of International Economics, 14 (3), 478-493.

[30] Lichtenberg, F. (1992). R \&D Investment and International Productivity Differences. NBER Working Paper, No. 4161.

[31] Lucas, R. (1988). On the Mechanics of Economic Development. Journal of Monetary Economics, 22, 3-42.
[32] Matthews, R. (1986). The economics of institutions and the sources of growth. The Economic Journal, 96 (384), 903-918.

[33] Onyinye, N., Idenyi, O. and Ifeyinwa, A. (2017). Effect of Capital Formation on Economic Growth in Nigeria. Asian Journal of Economics, Business and Accounting, 5 (1), 1-16.

[34] Orayo, J. and Mose, G. (2016). A Comparative Study on Contribution of Governance on Economic Growth in the East African Community Countries. International Journal of Regional Development, 3 (2), 89-106.

[35] Parente, S. and Prescott E. (1994). Barriers to Technology Adoption and Development. J Polit Econ, 102 (2), 298-321.

[36] Pere, E. (2015). The Impact of Good Governance in the Economic Development of Western Balkan Countries. European Journal of Government and Economics, 4 (1), 2545.

[37] Petrakos, G., Paschalis, A. and Sotiris, P. (2007). Determinants of Economic Growth: The Experts' View, DYNREG Dynamic Regions in a Knowledge Driven Global Economy Lessons and Policy Implications for the EU WORKING PAPERS, No 20.

[38] Phillips, P. C. B. and Hansen, B. (1990). Statistical Inference in Instrumental Variables Regression with I (1) Processes. The Review of Economic Studies, 57 (1), 99-125.

[39] Podrecca, E. and Carmeci, G. (2001). Fixed Investment and Economic Growth: New results on Causality. Applied Economics, 33 (2), 177-182.

[40] Razmi, M. J. and Refaei, R. (2013). The Effect of Trade Openness and Economic Freedom on Economic Growth: The Case of Middle East and East Asian Countries. International Journal of Economics and Financial Issues, 3 (2), 376-385.

[41] Rodrik, D., (2000). Institutions for High-Quality Growth: What They are and How to Acquire Them. NBER Working Paper No. 7540.

[42] Romer, P. (1990). Endogenous Technological Change. Journal of Political Economy, 98 (5), 71-102.

[43] Romer, P. (1986). Increasing Returns and Long Run Growth. Journal of Political Economy, 94 (5), 1002-1037.

[44] Solow, R. (1956). A Contribution to the Theory of Economic Growth. Quarterly Journal of Economics, 70 (1), 65- 94.

[45] Tekin, R. (2012). Development Aid, Openness to Trade and Economic Growth in Least Developed Countries: bootstrap panel Granger causality analysis. Social and Behavioral Sciences, 62, 716-721.

[46] Ulku, H. (2004). R \&D Innovation and Economic Growth: An Empirical Analysis. IMF Working Paper 185.

[47] World Bank (1992). Governance and development, Report No. 10650. Washington, DC: The World Bank. World Bank: http://www.worldbank.org/en/search?q=governance\%20indica tors. 